\title{
The impact of contract duration on the cost of cash retention
}

Article

Accepted Version

Hughes, W., Hillebrandt, P. and Murdoch, J. (2000) The impact of contract duration on the cost of cash retention. Construction Management and Economics, 18 (1). pp. 11-14. ISSN 01446193 doi: https://doi.org/10.1080/014461900370906 Available at https://centaur.reading.ac.uk/4300/

It is advisable to refer to the publisher's version if you intend to cite from the work. See Guidance on citing.

To link to this article DOI: http://dx.doi.org/10.1080/014461900370906

Publisher: Taylor \& Francis

All outputs in CentAUR are protected by Intellectual Property Rights law, including copyright law. Copyright and IPR is retained by the creators or other copyright holders. Terms and conditions for use of this material are defined in the End User Agreement.

\section{www.reading.ac.uk/centaur}

\section{CentAUR}

Central Archive at the University of Reading

Reading's research outputs online 


\title{
The impact of contract duration on the cost of cash retention
}

\author{
Will Hughes ${ }^{1}$, Patricia Hillebrandt ${ }^{1}$ and John Murdoch $^{2}$ \\ ${ }^{1}$ Department of Construction Management \& Engineering, University of Reading, \\ PO Box 219, RG6 6AW, UK \\ ${ }^{2}$ Department of Law, University of Reading, PO Box 217, RG6 6AW, UK
}

\begin{abstract}
Cash retention is a common means of protecting an employer from a contractor's insolvency as well as ensuring that contractors finish the work that they start. Similarly, contractors withhold part of payments due to their sub-contractors. Larger contracts tend to be subjected to smaller rates of retention. By calculating the cost of retention as an amount per year of a contract, it is shown that retention is far more expensive for firms whose work consists of short contracts. The extra cost is multiplied when the final payment is delayed, as it often is for those whose work takes place at the beginning of a project. This may explain why it is that main contractors are a lot less interested than sub-contractors in alternatives to cash retention, such as retention bonds.
\end{abstract}

Keywords; bonds, cash flow, contract, finance, retention.

\section{Introduction}

Most construction contracts are subject to cash retention (Hughes et al. 1998). This means that whenever a payment is made to a contractor by an employer, a small proportion is kept back. This proportion is usually in the region of 3 to 5\% (see for example, (Joint Contracts Tribunal 1998)). The primary purpose of this retention is to provide a fund for the employer in the event that the contractor fails to perform because of insolvency. A secondary purpose 
is to motivate the contractor to complete any minor outstanding items and repair defects after the work is finished.

Usually, half of the retention is released when the project reaches "practical completion” or “substantial completion”, an event which is commonly identified in construction contracts and defined as the point at which the work is completed for all practical purposes and any remaining defects are trivial. One characteristic of this event is that it marks the commencement of the "defects liability period" (DLP), usually of six months. Certain defects (defined in the contract) which occur or are noticed during this period may be entered in a list of defects (snagging list) which will be presented to the contractor at (or shortly after) the end of the period so that the contractor can put them right at his own expense. Once this is done, the remainder of the retention is released (Murdoch and Hughes 1996).

Standard form contracts, such as those published by the UK's Joint Contracts Tribunal (Joint Contracts Tribunal 1998), recommend that retention is set at $5 \%$, unless the contract value is high, in which case a lower rate should be used. This seems to make sense, because on large projects retention can amount to a large sum. However, further analysis of the impact of cash retention on the finances of construction firms, especially sub-contractors, reveals a different picture. This is important as nearly all construction work is sub-contracted (Hughes et al. 1997).

\section{Calculating the annual equivalent cost of retention}

Recent research (Hughes et al. 1998) considered the purposes, uses and costs of various kinds of financial protection in construction (bonds, retentions, guarantees, etc.). That research considered the full range of options available to those entering into construction contracts, assessing the uses, merits and costs of each. As part of the research, we interviewed 
practitioners, ran five focus groups, each representing different interests within the industry, conducted and analysed a postal survey which produced approximately 200 responses and analysed financial information supplied by Dun and Bradstreet on over 5,000 construction companies in the UK. Among other things, the research revealed that the median rate for retention was $3 \%$ and ranged from 1 to $15 \%$. Cash retention is not the only means of providing financial protection to those who employ contractors or sub-contractors. One commonly sought alternative is a retention bond, another is a parent company guarantee. In comparing the relative costs of alternative financial protection arrangements, it was found necessary to bring the various kinds of mechanism to a common base. The basis chosen for comparing different arrangements was the cost per year of the contract. The operation of the retention mechanism is an opportunity cost to the contractor or sub-contractor, equivalent to the loss of interest on the amount of money withheld. This has to be balanced against income for the duration of the contract work. In making these comparisons (reported in Hughes et al. 1998), it became clear that differing arrangements for cash retention had very different impacts on the cost to the contractor (or sub-contractor). In particular, withholding the final release of retention for long periods adds an excessive burden to those whose work takes place early in the project.

During the course of the contract, the amount withheld increases as the value of work done increases. At the beginning of the work, none is withheld, at the end, the full amount of retention is withheld. Although the work does not progress linearly (an 'S'-curve is characteristic of the way that construction work progresses), for the purposes of calculating the interest on the amount of money retained, and the period for which it is held, a straight line is a good approximation. The period for which the monies are outstanding varies slightly with the shape of the ' $\mathrm{S}$ ' curve, influencing the loss of interest on retention. However, this is 
insignificant in comparison to the impact of the duration of the DLP, especially in relation to its duration relative to the contract period. The size of the retention fund averages out to an amount that is approximately equal to half of the retention for the period of the contract:

$$
\frac{r}{2} \times d
$$

where $r$ is the rate of retention (\%) and $d$ is the duration of the contract (months).

At the point of practical completion, half of the retention is released, and the remaining half is held until the end of the defects liability period:

$$
\frac{r}{2} \times p
$$

where $p$ is the duration of the defects liability period (months). Adding eqn 1 to eqn. 2:

$$
\frac{r}{2} \times(d+p)
$$

This gives the total amount that is withheld from the contractor. However, the contractor has to finance this from income earned only during the contract period, $d$, so the annual equivalent is calculated by dividing eqn. (3) by $d$ :

$$
\frac{r}{2} \times \frac{(d+p)}{d}
$$

To illustrate this, Figure 1 shows an example arrangement where 5\% retention runs for the period of a twelve month contract. At practical completion (12 months), half of the retention is released and 6 months later, the remainder is released. Thus, a contract that earns income for 12 months involves retention which approximates to $2.5 \%$ (half the rate of retention) for 
18 months (the duration of the project plus the defects liability period), giving an annual equivalent of 2.5 x 18/12, i.e. $3.75 \%$.

\section{The use of retention in practice}

During the research (Hughes et al. 1998), it became clear that retention may be withheld for very long periods, especially on sub-contracts, even of relatively small value. In addition, sometimes, main contractors pay late or even do not pay at all. The longest periods are usually experienced by those sub-contractors whose work is early in the process, such as piling sub-contractors. It is quite common for the final release of retention to sub-contractors to be tied to the main contractor's final payment date. The research showed that in practice such sub-contractors may be kept waiting for $2.5 \%$ of their money for perhaps two years after they have finished their work. If this is reduced to the cost per month of contract, an interesting pattern emerges. Table 1 illustrates some different scenarios for cash retention, all of which are routinely encountered in practice. For the purposes of illustration, a rate of retention of $5 \%$ has been assumed in the formula given at (4). The data in columns 2 to 4 of the data are calculated from the formula, and these are converted to a cost, assuming a rate of interest, or opportunity cost, of 6\% p.a., in columns 5 to 7.

In calculating the cost to the contractor, it seems that the cost of retention to the contractor is more for short projects than for long ones. This is because of the fact that half of the retention is held for (typically) six months after practical completion. On a short project, this six-month period has a much bigger impact than on a longer one. Table 1 shows why this is so and Figure 2 displays the same data. Here, the impact of varying the duration of the defects liability period is clear, especially in relation to shorter contract periods. 


\section{Current views on retention}

Since the Latham Report (Latham 1994) there have been numerous calls in the UK to find alternatives to cash retention (Construction News 1997, Cook 1997, Klein 1997, Latham 1997). One reason for dissatisfaction with retention funds is the uncertainty that surrounds the status of a sub-contractor's retention in the event of main contractor insolvency (McCartney 1992, Powell-Smith 1991). The problem here is that if the main contractor goes insolvent during a project, it is very difficult for sub-contractors to obtain the funds held by the main contractor as retention, unless special arrangements have been made (Huxtable 1992). The usual proposal for overcoming this problem is a retention bond, where a contractor (or sub-contractor) would find bank or insurer to guarantee their solvency for the duration of the project (Latham 1997). While popular among sub-contractors because of the appeal of being paid $100 \%$ of the work certified as finished each month, these calls have largely been resisted by main contractors, primarily because they would be out of pocket if they sought retention bonds from their sub-contractors when they face cash retention on their own receipts (in this situation they would have to pay their sub-contractors $100 \%$ of the value of the work done even though they were not receiving $100 \%$ of the value of the work done from their employers).

Retention remains the main mechanism for protecting the employer within standard forms of building contract (see, for example JCT 80, Joint Contracts Tribunal 1998). Indeed, the fact is that standard form contracts like JCT 80 include a footnote to the effect that on larger contracts, lower rates of retention may be used, indicating that those who negotiate and draft standard forms believe the impact to be less for shorter contracts, justifying a higher percentage rate of retention 


\section{Conclusions}

The analysis in Table 1 explains why the issue is so much more important for sub-contractors working on short contracts at the outset of a project. These sub-contractors frequently have to await completion of the entire project before their final account is settled, placing them at the expensive end of the line in Figure 2, whereas main contractors and those sub-contractors whose work is at the end of the project will find that the cost of retention is marginal. Although this phenomenon is most marked on short sub-contracts with long delays to the final payment, the situation is typified by piling sub-contracts, which are encountered on most large projects. Moreover, the notion that retention should be at a lower rate for large projects seems to ignore the greater impact that cash retention has on the cash flow of those firms whose work consists of small projects.

\section{Acknowledgements}

The authors are indebted to the four anonymous referees for their constructive comments on the first draft of this paper.

\section{References}

Construction News (1997) Minister urges specialists to back use of retention bonds. Construction News. 6506, 13 March 97, 3.

Cook, A. (1997) M\&E giants ban retentions. Building. 262(19), 16 May 1997, 7.

Hughes, W. P., Gray, C. and Murdoch, J. R. (1997) Specialist trade contracting: report. Special Report 1997 SP 138 London: Construction Industry Research and Information Association.

Hughes, W. P., Hillebrandt, P. and Murdoch, J. R. (1998) Financial protection in the UK building industry: bonds, retentions and guarantees. Spon: London. 
Huxtable, J. (1992) Surviving main contractor insolvency: a practical guide. Aldershot: Confederation of Construction Specialists.

Joint Contracts Tribunal (1998) Standard form of building contract 1998 edition: private with quantities. RIBA Publications: London.

Klein, R. (1997) Questions for cash. Building. 262(14), 11 April 97, 38-39.

Latham, M. (1994) Constructing the team: final report of the government/industry review of procurement and contractual arrangements in the UK construction industry. HMSO: London.

Latham, M. (1997) Giving up retentions. Building. 262(23), 13 Jun 1997, 28.

McCartney, P. (1992) The status of retention funds in insolvency. Construction Law Journal, 8(6), 360-371.

Murdoch, J. and Hughes, W. (1996) Construction contracts: law and management. 2ed. Spon: London.

Powell-Smith, V. (1991) Payment of sub-contractors when main contractor is insolvent. International Construction Law Review, 8(2), 241-246. 
Proportion of contract value in

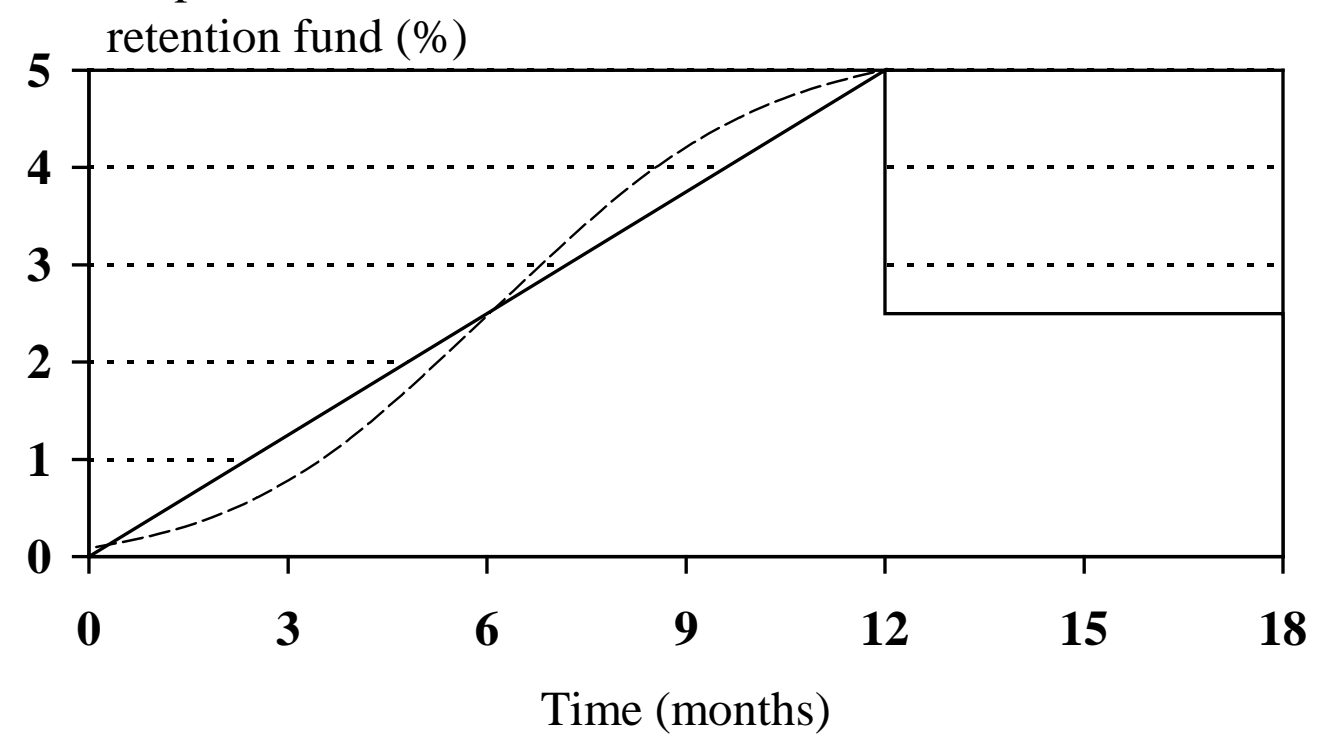

Figure 1: How the amount of the retention fund changes during a contract

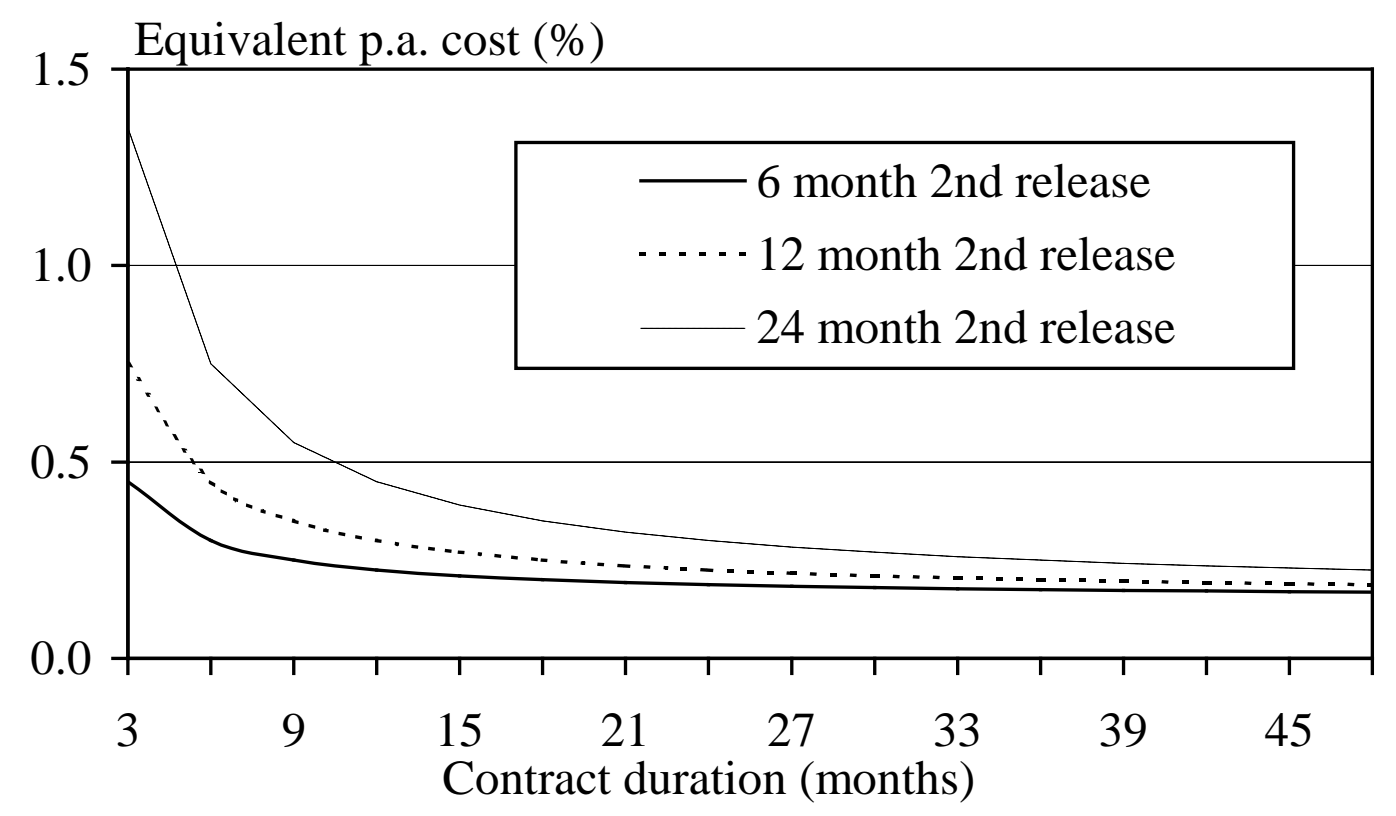

Figure 2: Cost of various retention arrangements per year of contract 
Table 1: Calculation of annual equivalent cost of various retention arrangements

\begin{tabular}{ccccccc}
\hline & \multicolumn{2}{c}{$\begin{array}{c}\text { Annual equivalent rate of retention } \\
\text { per year of contract (\%) }\end{array}$} & \multicolumn{3}{c}{$\begin{array}{c}\text { Annual equivalent rate per year of } \\
\text { contract (\%) }\end{array}$} \\
\cline { 2 - 7 } $\begin{array}{c}\text { Duration of } \\
\text { contract } \\
\text { (months) }\end{array}$ & $\begin{array}{c}\mathbf{6} \text { months } \\
\text { DLP }\end{array}$ & $\begin{array}{c}\mathbf{1 2} \text { months } \\
\text { DLP }\end{array}$ & $\begin{array}{c}\mathbf{2 4} \text { months } \\
\text { DLP }\end{array}$ & $\begin{array}{c}\mathbf{6} \text { months } \\
\text { DLP }\end{array}$ & $\begin{array}{c}\text { 12 months } \\
\text { DLP }\end{array}$ & $\begin{array}{c}\text { 24 months } \\
\text { DLP }\end{array}$ \\
\hline 3 & & & & & & \\
6 & 7.50 & 12.50 & 22.50 & 0.45 & 0.75 & 1.35 \\
9 & 5.00 & 7.50 & 12.50 & 0.30 & 0.45 & 0.75 \\
12 & 4.17 & 5.83 & 9.17 & 0.25 & 0.35 & 0.55 \\
15 & 3.75 & 5.00 & 7.50 & 0.23 & 0.30 & 0.45 \\
18 & 3.50 & 4.50 & 6.50 & 0.21 & 0.27 & 0.39 \\
21 & 3.33 & 4.17 & 5.83 & 0.20 & 0.25 & 0.35 \\
24 & 3.21 & 3.93 & 5.36 & 0.19 & 0.24 & 0.32 \\
27 & 3.13 & 3.75 & 5.00 & 0.19 & 0.23 & 0.30 \\
30 & 3.06 & 3.61 & 4.72 & 0.18 & 0.22 & 0.28 \\
33 & 3.00 & 3.50 & 4.50 & 0.18 & 0.21 & 0.27 \\
36 & 2.95 & 3.41 & 4.32 & 0.18 & 0.20 & 0.26 \\
39 & 2.92 & 3.33 & 4.17 & 0.18 & 0.20 & 0.25 \\
42 & 2.88 & 3.27 & 4.04 & 0.17 & 0.20 & 0.24 \\
45 & 2.86 & 3.21 & 3.93 & 0.17 & 0.19 & 0.24 \\
48 & 2.83 & 3.17 & 3.83 & 0.17 & 0.19 & 0.23 \\
\hline
\end{tabular}

